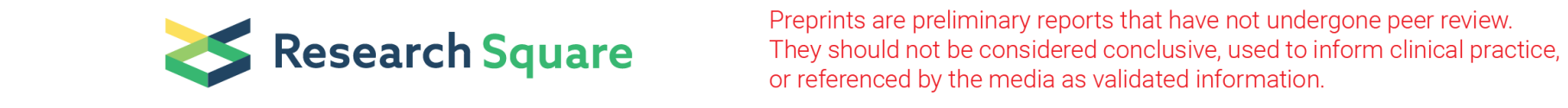

\title{
Growth And Elasticity Of Output Of MSME In India
}

\author{
SETAK PALAK ( $\square$ setakompalak@gmail.com ) \\ Berhampur University,Odisha https://orcid.org/0000-0003-0772-8216 \\ Dr.Sandhyarani Das \\ Berhampur University
}

Research

Keywords: Employment, Output, Elasticity

Posted Date: June 23rd, 2020

DOI: https://doi.org/10.21203/rs.3.rs-36142/v1

License: (ㅇ) (1) This work is licensed under a Creative Commons Attribution 4.0 International License. Read Full License 


\section{Abstract}

This paper analyses the phenomenon of growth in India through the lens of employment elasticity. Investigative results are imitative for decompositions of both the level and change of combined employment elasticity in terms of sectoral elasticities, relative development and employment shares. Estimates of these decompositions are presented with employment and output data from related sources for both economies. In India, MSME sector was the key determinant of both the level and change of aggregate elasticity. In India, service is the most important determinant of the level, but manufacturing remains an important driver of changes in aggregate employment elasticity. The core objective of the present paper remains to analyse the growth and elasticity output relationship in this sector, so the study contains the productivity analysis of the MSME sector in India. This will unleash the role of the various inputs and output in production here. Extended Cobb Douglas Production Function has been utilised on the secondary, cross section data of MSMEs of India. Different variables like employment, Number of working enterprises, input, output and capital are selected to analyze their effects of MSMEs.

\section{Introduction}

In the last few years, the phenomenon of a marked slowdown in the growth of employment has been noticed in many countries across the world. This is often to as jobless growth. To be sure, it's not the case that employment has not been rising at all, even output has grown. Rather, for each percentage point of output growth, the associated growth rate of employment has fallen. Hence, a more precise characterisation would be that the output elasticity of employment, which measures the responsiveness of employment to output growth, has been declining over time.

In addition to the almost secular decline in MSME employment elasticities over the long run, asymmetric fluctuations over phases of the business cycles have also been observed. For instance, Basu and Foley (2013) note that the responsiveness of employment to output growth in the Indian economy has been different between the downturn and recovery phases of business cycles. In particular, they point out that while labour is shed during the economic slowdown, as is to be expected, the pick-up of employment during the recovery phase has been weakening since the early 1990 s.

While these asymmetric employment responses at business cycle frequencies are interesting and important phenomena, the focus of this paper on longer term response of employment to output changes. In this respect, India is no exception to the global trend of failing labour absorption capacity of output growth. Even as the growth rate of real GDP in India has accelerated since the late-1980s, MSME employment growth has slowed down. Thus, the employment growth associated with each percentage point growth of real value added has drifted down over time. We point out the MSME aggregate output elasticity of employment, which measures the percentage change in employment for every percentage.

change in real value added, for India. It is immediately apparent from the figure that there is a clear downward trend in the output elasticity of employment over time in both countries.

The downward trend in employment elasticity highlights the key challenge facing policy makers in contemporary in India. For a poor and labour surplus economy like India, MSME employment growth is by far the most important mechanism for rapid and robust poverty reduction. The fact that employment elasticity has been declining means that the capability of output growth to absorb labour is weakening. To kick start an employment-intensive growth strategy, it will be necessary to address the issue of employment elasticity.

In India, a large poor country to be dominant sector in terms of employment even as MSME sectors have become important in terms of output. Total employment elasticity, i.e., employment elasticity of the entire economy, is a blunt tool to investigate the complex of phenomenon that underlies declining labour absorption. Thus it would be analytical more rewarding to adopt a sectoral perspective as has been the practice much of the previous literature. An analysis of changes explain that changes in sectoral elasticities and changes in relative sectoral growth rates have both been important drivers of changes in aggregate employment elasticity, with the manufacturing sector playing an important role.

\section{Literature Review}

Admassie and Matambalya (2002) explain technical efficiency for small and medium scale enterprises, in Tanzania. The authors collect primary data from period 1999 to 2000, using Cobb-Douglas stochastic frontier production function. The finding reveals that in Tanzanian SMEs, there is a high level of technical inefficiency which reduces their output levels significantly. However adequate supply of inputs markets, credit facilities, infrastructure and training can raise the productivity of firms.

Majumder (2004) discusses the productivity growth in small manufacturing enterprises in Bangladesh. The author has studied the role of inputs, technological progress and learning by doing in enhancing productivity of SMEs from period 1994-1995 and 2000-2001, using Total Factor Productivity growth (TFPG) and Stochastic frontier Production function in its Translog form. The finding reveals that technological improvement and technological improvement and technological diffusion is necessary for pure technical.

progress. The author suggests improvement of technology to enhance the productivity growth.

Zahid and Mokhtar (2007) estimated the technical efficiency levels of Malaysian manufacturing SMEs. The Cobb-Douglas stochastic production frontier is applied. The results presented indicate that all coefficients in the stochastic frontier production function are positive and significant. This indicates that inputs have a positive relationship, and are significant, to manufacturing SMEs' production levels. The average technical efficiency of overall 
manufacturing SMEs is 0.76 percent. It can be indicated that Malaysian manufacturing SMEs have approximately 24 percent of inefficiency in their production process.

Kumar and Basu (2008) present the perspective of productivity growth in Indian food industry. The authors collect secondary data during the period from 1988-1989 to 2004-2005 using log linear regression model and a data envelopment analysis technique. The findings reveals that Indian food industry is facing inefficiency due to low rate of technological progress which depends on mode of organization and various economic and institutional factors therefore it is necessary to encourage imports along with research and development.

\section{Objectives of the Study}

1. Growth and elasticity of Employment in MSMEs in India.

2. To analyse the input output relationship of MSMEs in India.

\section{Results And Discussion}

In this article we have discussed regarding Employment elasticity accept the responsiveness of employment of changes in output. There are two common ways of measuring the output elasticity of employment. The first method calculates the point elasticity by regressing log-employment on logoutput, where the coefficient on the latter is the estimate of elasticity. Since estimation of point elasticity relies on a regression, a researcher requires substantial data points to put it into practice. Often, enough data is not available to run regressions. Researchers turn to the second method, which calculates the arc elasticity as the ratio of the growth rate of employment and growth rate of output over some period of time. This makes regression analysis infeasible. Hence, we compute and work with arc elasticity.

\section{Methods/experimental}

The empirical analysis in this paper is based on cross-sectional secondary data. For the analysis we have used different statistical tools, i.e. correlation matrix, simple regression analysis, ANOVA Test, Elasticity, and Cobb-Douglas Production Function.

\section{Growth of MSMEs in India}

Table - 1 Performance of MSME sector in India

\begin{tabular}{|c|c|c|c|c|}
\hline Year & No. of Working Enterprise & $\begin{array}{l}\text { Employment } \\
\text { (in lakh) }\end{array}$ & Market value of FAs (in crore) & $\begin{array}{l}\text { Gross output } \\
\text { (in crore) }\end{array}$ \\
\hline 2001-02 & 105.21 & 249.33 & 154349 & 282270 \\
\hline $2002-03$ & 109.49 & 260.21 & 162317 & 314850 \\
\hline 2003-04 & 113.95 & 271.42 & 170219 & 364547 \\
\hline 2004-05 & 118.59 & 282.57 & 178699 & 429796 \\
\hline 2005-06 & 123.42 & 294.91 & 188113 & 497842 \\
\hline $2006-07$ & 361.76 & 805.23 & 868543.79 & 1351383.45 \\
\hline 2007-08 & 377.37 & 842.23 & 917437.46 & 1435179.26 \\
\hline 2008-09 & 393.70 & 881.14 & 971407.49 & 1524234.83 \\
\hline $2009-10$ & 410.82 & 922.19 & 1029331.46 & 1619355.53 \\
\hline $2010-11$ & 428.77 & 965.69 & 1094893.42 & 1721553.42 \\
\hline $2011-12$ & 447.73 & 1012.59 & 1176939.36 & 1834332.05 \\
\hline $2012-13$ & 467.54 & 1061.40 & 1268763.67 & $\star \star$ \\
\hline 2013-14 & 488.46 & 1114.29 & 1363700.54 & ** \\
\hline 2014-15 & 510.57 & 1171.32 & 1471912.94 & ** \\
\hline Average & 318.38 & 723.89 & 786901.74 & 1034122.14 \\
\hline CAGR & $11.94 \%$ & $11.68 \%$ & $17.48 \%$ & $14.30 \%$ \\
\hline \multicolumn{5}{|c|}{ Source: MSME Annual Report 2017-18, Gol } \\
\hline ** Data nc & t Available & & & \\
\hline
\end{tabular}

Above table 1 indicate the growth in Numbers of Working Enterprises, Employment, Market Value of Fixed Assets and Gross Output of MSME from 200102 to 2014-15. In 2001-02 Number of working enterprises are 105.21, it increases to 510.57 in 2014-15. The employment position shows 249.33 lakh in 
2001-12 and it raised to 1171.32 lakh in 2014-15. Market value of fixed assets point out 154349 crore in 2001-12, now it also continuously went up to 1471912.94 crore in 2014-15. The gross output increased from 282270 crore to 1834332.05 crore in between 2001-02 to 2014-15.

\section{Importance of Output Elasticity of Employment}

An important objective of development planning in India has been to provide for increasing employment opportunities not only to meet the backlog of the unemployed but also the new additions to the labour force. The economic reforms have aimed at fostering labour intensive production in India. The employment intensity of economic growth can be understood by the size of output elasticity of employment. In other words the concept of output elasticity of employment in a particular sector of the economy helps in understanding the extent of labour absorption capacity of that sector in the Economy. The responsiveness of employment to the changes in macro economic situation (gross domestic product or gross output) and the presence of shift in the responsiveness of employment to the changes in gross output owing to new economic policy introduced since July 1991 , needs to be empirically examined by fitting an employment function with an interaction variable to time series data points. The present not is an effort in this direction. From the prospective of the macro production function of the economy, the use of labour with complementary factors of production produces national output or gross domestic product. The demand function for labour can be derived either from Cobb Douglas function production function or Constant Elasticity of Substitution (CES) production function by solving the marginal product of labour equation for labour input variable.

Table - 2 Exports from Micro and Small Enterprises (MSEs) in Relation to Total Merchandise Exports

\begin{tabular}{|llll|}
\hline $\begin{array}{l}\text { Financial } \\
\text { Year }\end{array}$ & Total Exports (US \$ billions) & Exports of MSE products (US \$ billions) & \% share of MSE in total exports \\
\hline $2001-02$ & 43.83 & 14.94 & 34.1 \\
\hline $2002-03$ & 52.72 & 17.77 & 33.7 \\
\hline $2003-04$ & 63.84 & 21.25 & 33.3 \\
\hline $2004-05$ & 83.54 & 27.69 & 33.1 \\
\hline $2005-06$ & 103.09 & 33.94 & 32.9 \\
\hline $2006-07$ & 126.41 & 40.31 & 31.9 \\
\hline $2007-08$ & 163.13 & 50.2 & 30.8 \\
\hline $2008-09$ & 185.3 & 66.35 & 35.8 \\
\hline $2009-10$ & 178.75 & 82.49 & 46.1 \\
\hline $2010-11$ & 251.14 & 111.4 & 44.4 \\
\hline $2011-12$ & 305.96 & 131.48 & 43 \\
\hline $2012-13$ & 300.4 & 128.16 & 42.7 \\
\hline $2013-14$ & 314.42 & 132.9 & 42.3 \\
\hline $2014-15$ & 310.35 & 138.94 & 49.8 \\
\hline $2015-16$ & 262.29 & 130.65 & $2015-16$, New Delhi. \\
\hline Source: Union Ministry of Finance, Economic Division (2016), Economic Survey & & \\
\hline
\end{tabular}

Table 2 shows export from micro and small enterprises (MSEs) in relation to total merchandise exports 2001-02 to 2015-16. Total export indicates 43.83 billion in 2001-02 and it increased to 262.29 billion in 2015-16 which is 6 times increased against 2001-02. The MSE total exports 14.94 billion in 2001-02 which rise to 128.16 billion in 2015-16. The percent share of MSE in total exports 34.1 in 2001-02 and it increased to 49.8 billion in 2015-16.

Table -3 
Table 3

shows that Gross output, Total input, Total Input, Input output ratio, Export, Percentage of export, Net worth and net growth rate of MSME in India. The highest Gross output indicate state of Maharashtra which is Rs. 110705.08 crore and lowest state is Andaman and Nicobar which is Rs. 51.75 crore.

State of Maharashtra is highest input in the country i.e. Rs. 70765.80 crore and lowest input is Rs. 55.59 crore in the state Andaman and Nicobar. The highest and lowest input output ratio 209 and 1.3 respectively. Uttar Pradesh is highest export state in MSME in India which indicate Rs. 14342.40 crore in the current period and lowest Export states are Mizorm, Andaman \& Nicobar and Arunchal Pradesh i.e. Rs. 1 crore each. The highest percentage of export is 19 percent in the state of Uttar Pradesh and lowest one is 1 percent. The highest networth is Rs. 50514.11 crore in the state of Uttar Pradesh and lowest

\begin{tabular}{|c|c|c|c|c|c|c|c|c|c|c|}
\hline SL.NO & STATE/UT & $\begin{array}{l}\text { GROSS } \\
\text { OUTPUT }\end{array}$ & $\begin{array}{l}\text { TOTAL } \\
\text { INPUT } \\
\text { NALUE } \\
\text { IN } \\
\text { CRORE) }\end{array}$ & $\begin{array}{l}\text { INPUT } \\
\text { OUT } \\
\text { PUT } \\
\text { RATIO } \\
\text { OF } \\
\text { GROSS } \\
\text { OUT } \\
\text { PUT \& } \\
\text { TOTAL } \\
\text { INPUT }\end{array}$ & $\begin{array}{l}\text { EXPORT } \\
\text { (VALU IN } \\
\text { CRORE) }\end{array}$ & $\begin{array}{l}\text { GROSS } \\
\text { OUTPUT }\end{array}$ & $\begin{array}{l}\text { PERCENTAGE } \\
\text { OF EXPORT }\end{array}$ & $\begin{array}{l}\text { NET } \\
\text { WORTH } \\
\text { (VALUE IN } \\
\text { CRORE) }\end{array}$ & $\begin{array}{l}\text { TOTAL } \\
\text { INPUT } \\
\text { NALUE } \\
\text { IN } \\
\text { CRORE }\end{array}$ & $\begin{array}{l}\text { RATIO } \\
\text { OF NET } \\
\text { GROWTH } \\
\text { RATE TO } \\
\text { TATAOL } \\
\text { OUTPUT }\end{array}$ \\
\hline NA & ALL INDIA & 707510.27 & 443313.7 & 1.6 & 67913.85 & 707510.27 & $10 \%$ & 415303.41 & 443313.7 & 0.9 \\
\hline 1 & TAMIL NADU & 65281.95 & 38465.19 & 1.7 & 10048.84 & 65281.95 & $15 \%$ & 39914.81 & 38465.19 & 1.0 \\
\hline 2 & GUJARAT & 38438.44 & 14164.82 & 2.7 & 4962.45 & 38438.44 & $13 \%$ & 26504.39 & 14164.82 & 1.9 \\
\hline 3 & $\begin{array}{l}\text { UTTAR } \\
\text { PRADESH }\end{array}$ & 74065.17 & 44336 & 1.7 & 14342.4 & 74065.17 & $19 \%$ & 50514.11 & 44336 & 1.1 \\
\hline 4 & KERALA & 24122.65 & 14163.88 & 1.7 & 2278.82 & 24122.65 & $9 \%$ & 17954.16 & 14163.88 & 1.3 \\
\hline 5 & KARNATAKA & 41060.27 & 24004.83 & 1.7 & 5470.89 & 41060.27 & $13 \%$ & 17666.17 & 24004.83 & 0.7 \\
\hline 6 & $\begin{array}{l}\text { MADHYA } \\
\text { PRADESH }\end{array}$ & 26191.6 & 19748.45 & 1.3 & 862.79 & 26191.6 & $3 \%$ & 11348.92 & 19748.45 & 0.6 \\
\hline 7 & MAHARASHTRA & 110705.08 & 70765.8 & 1.6 & 5484.26 & 110705.08 & $5 \%$ & 88691.52 & 70765.8 & 1.3 \\
\hline 8 & RAJASTAN & 39402.23 & 29883.85 & 1.3 & 4977.93 & 39402.23 & $13 \%$ & 17218.16 & 29883.85 & 0.6 \\
\hline 9 & BIHAR & 4661.53 & 2561.21 & 1.8 & 7.98 & 4661.53 & $1 \%$ & 2458.95 & 2561.21 & 1.0 \\
\hline 10 & PUNJAB & 62099.27 & 43484.18 & 1.4 & 4700.68 & 62099.27 & $8 \%$ & 28997.51 & 43484.18 & 0.7 \\
\hline 11 & $\begin{array}{l}\text { ANDHRA } \\
\text { PRADESH }\end{array}$ & 30102.26 & 19883.29 & 1.5 & 1646.69 & 30102.26 & $5 \%$ & 16272.42 & 19883.29 & 0.8 \\
\hline 12 & WEST BENGAL & 26906.61 & 18359.59 & 1.5 & 2152.61 & 26906.61 & $8 \%$ & 12972.42 & 18359.59 & 0.7 \\
\hline 13 & HARYANA & 43762.97 & 28653.64 & 1.5 & 4833.94 & 43762.97 & $11 \%$ & 25367.71 & 28653.64 & 0.9 \\
\hline 14 & UTTARAKHANDA & 13370.36 & 7878.73 & 1.7 & 447.35 & 13370.36 & $3 \%$ & 3772.88 & 7878.73 & 0.5 \\
\hline 15 & CHHATTISGARH & 6182.27 & 4487.24 & 1.4 & 89.22 & 6182.27 & $1 \%$ & 3813.36 & 4487.24 & 0.8 \\
\hline 16 & ASSAM & 9389.2 & 4746.55 & 2.0 & 32.91 & 9389.2 & $0 \%$ & 4262.53 & 4746.55 & 0.9 \\
\hline 17 & ORISSA & 14746.08 & 7723.4 & 1.9 & 440.76 & 14746.08 & $3 \%$ & 6214.42 & 7723.4 & 0.8 \\
\hline 18 & JHARKHAND & 4170.1 & 2618.77 & 1.6 & 69.7 & 4170.1 & $2 \%$ & 108.77 & 2618.77 & 0.0 \\
\hline 19 & $\begin{array}{l}\text { JAMMU\& } \\
\text { KASHMIR }\end{array}$ & 14516.78 & 8391.57 & 1.7 & 2071.21 & 14516.78 & $14 \%$ & 6887.32 & 8391.57 & 0.8 \\
\hline 20 & $\begin{array}{l}\text { HIMACHAL } \\
\text { PRADESH }\end{array}$ & 11786.29 & 7584.04 & 1.6 & 312.02 & 11786.29 & $3 \%$ & 4932.8 & 7584.04 & 0.7 \\
\hline 21 & MANIPUR & 199.8 & 106.08 & 1.9 & 0.15 & 199.8 & $1 \%$ & 444.88 & 106.08 & 4.2 \\
\hline 22 & DELHI & 19471.1 & 12846.95 & 1.5 & 1233.52 & 19471.1 & $6 \%$ & 10817.25 & 12846.95 & 0.8 \\
\hline 23 & MIZORAM & 309.9 & 127.66 & 2.4 & 0 & 309.9 & $1 \%$ & 387.48 & 127.66 & 3.0 \\
\hline 24 & MEGHALAYA & 447.31 & 295.25 & 1.5 & 0.07 & 447.31 & $1 \%$ & 218.71 & 295.25 & 0.7 \\
\hline 25 & GOA & 6627.57 & 4688.63 & 1.4 & 472.27 & 6627.57 & $7 \%$ & 4157.68 & 4688.63 & 0.9 \\
\hline 26 & $\begin{array}{l}\text { DADAR \& NAGAR } \\
\text { HAVEL }\end{array}$ & 2077.14 & 728.81 & 2.9 & 5.51 & 2077.14 & $1 \%$ & 2297.7 & 728.81 & 3.2 \\
\hline 27 & PUDUCHERRY & 5614.33 & 4160.76 & 1.3 & 238.77 & 5614.33 & $4 \%$ & 2002.08 & 4160.76 & 0.5 \\
\hline 28 & TRIPURA & 608.3 & 389.73 & 1.6 & 8.89 & 608.3 & $1 \%$ & 291.03 & 389.73 & 0.7 \\
\hline 29 & NAGALAND & 1396.04 & 778.54 & 1.8 & 5.17 & 1396.04 & $1 \%$ & 2642.19 & 778.54 & 3.4 \\
\hline
\end{tabular}




\begin{tabular}{|c|c|c|c|c|c|c|c|c|c|c|}
\hline SL.NO & STATE/UT & $\begin{array}{l}\text { GROSS } \\
\text { OUTPUT }\end{array}$ & $\begin{array}{l}\text { TOTAL } \\
\text { INPUT } \\
\text { (VALUE } \\
\text { IN } \\
\text { CRORE) }\end{array}$ & $\begin{array}{l}\text { INPUT } \\
\text { OUT } \\
\text { PUT } \\
\text { RATIO } \\
\text { OF } \\
\text { GROSS } \\
\text { OUT } \\
\text { PUT \& } \\
\text { TOTAL } \\
\text { INPUT }\end{array}$ & $\begin{array}{l}\text { EXPORT } \\
\text { (VALU IN } \\
\text { CRORE) }\end{array}$ & $\begin{array}{l}\text { GROSS } \\
\text { OUTPUT }\end{array}$ & $\begin{array}{l}\text { PERCENTAGE } \\
\text { OF EXPORT }\end{array}$ & $\begin{array}{l}\text { NET } \\
\text { WORTH } \\
\text { (VALUE IN } \\
\text { CRORE) }\end{array}$ & $\begin{array}{l}\text { TOTAL } \\
\text { INPUT } \\
\text { NALUE } \\
\text { IN } \\
\text { CRORE }\end{array}$ & $\begin{array}{l}\text { RATIO } \\
\text { OF NET } \\
\text { GROWTH } \\
\text { RATE TO } \\
\text { TATAOL } \\
\text { OUTPUT }\end{array}$ \\
\hline 30 & CHANDIGARH & 1684.45 & 1028.59 & 1.6 & 103.16 & 1684.45 & $6 \%$ & 777.88 & 1028.59 & 0.8 \\
\hline 31 & $\begin{array}{l}\text { ANDAMAN \& } \\
\text { NICOBAR }\end{array}$ & 111.75 & 55.59 & 2.0 & 1 & 111.75 & $1 \%$ & 48.6 & 55.59 & 0.9 \\
\hline 32 & DAMAN \& DIU & 7712.89 & 6028.95 & 1.3 & 611.59 & 7712.89 & $8 \%$ & 3421.32 & 6028.95 & 0.6 \\
\hline 33 & $\begin{array}{l}\text { ARUNACHAL } \\
\text { PRADESH }\end{array}$ & 237.21 & 137.86 & 1.7 & 1 & 237.21 & $1 \%$ & 187.97 & 137.86 & 1.4 \\
\hline 34 & SIKKIM & 51.37 & 35.27 & 1.5 & 1.3 & 51.37 & $3 \%$ & 35.48 & 35.27 & 1.0 \\
\hline
\end{tabular}

Table - 4. Descriptive Statistics

Table 4

indicates the Descriptive statistics in MSME in India. The average working enterprises is 86887 and employment shows 517194 person. The market value of fixed assets is Rs. 26341 crore. Total input value shows Rs. 24629 crore and net worth average value of MSME sector is Rs. 23025 crore. The standard deviation pointout 261456 in number of working enterprises and employment standard deviation is 1552146. Market value of fixed assets standard deviation is 77649 with gross output standard deviation is 117324. In the case of Skewness 5.45 (statistics) in working enterprises, 4.99 market value of fixed assets and 5.43 in net worth. The standard error of Skewness is 0.39 in all the factors which indicates positive performance in MSME sector. The Kurtosis of Descriptive statistics shows 32 in four factors i.e. Employment, Gross output, Total input, GAV and net worth is 31 . The standard error of Kurtosis is 0.77 each in all the factors of MSME sector in India.

\begin{tabular}{|c|c|c|c|c|c|c|c|c|c|}
\hline \multicolumn{10}{|l|}{ Descriptive Statistics } \\
\hline & $\mathrm{N}$ & Minimum & Maximum & Mean & Std. Deviation & Skewness & & Kurtosis & \\
\hline & Statistic & Statistic & Statistic & Statistic & Statistic & Statistic & $\begin{array}{l}\text { Std. } \\
\text { Error }\end{array}$ & Statistic & $\begin{array}{l}\text { Std. } \\
\text { Error }\end{array}$ \\
\hline $\begin{array}{l}\text { NUMBER OF WORKING } \\
\text { ENTERPRISES }\end{array}$ & 36 & 2 & 1563974 & 86887.44 & 261456.167 & 5.447 & .393 & 31.291 & .768 \\
\hline EMPLOYMENT(PERSON) & 36 & 2 & 9309486 & 517193.67 & 1552146.226 & 5.490 & .393 & 31.661 & .768 \\
\hline $\begin{array}{l}\text { ORIGINAL VALUE OF P\&M } \\
\text { (VALUE IN CORE }\end{array}$ & 36 & .0000 & 105024.6100 & 5834.710556 & 18498.6286181 & 4.875 & .393 & 25.271 & .768 \\
\hline $\begin{array}{l}\text { MARKET VALUE OF FIXED } \\
\text { (VALUE IN CORE) ASSETS }\end{array}$ & 36 & .0000 & 449138.4000 & 26341.022222 & 77648.9121833 & 4.992 & .393 & 26.780 & .768 \\
\hline GROSS OUTPUT & 36 & .0000 & 707510.2700 & 39306.126111 & 117324.4134337 & 5.579 & .393 & 32.424 & .768 \\
\hline $\begin{array}{l}\text { TOTAL INPUT (VALUE IN } \\
\text { CORE) }\end{array}$ & 36 & .0000 & 443313.7000 & 24628.538889 & 73561.9323916 & 5.568 & .393 & 32.331 & .768 \\
\hline GAV(VALUE IN CORE) & 36 & .0000 & 264196.5700 & 14677.587222 & 43859.2947341 & 5.560 & .393 & 32.267 & .768 \\
\hline EXPORT(VALUE IN CORE) & 36 & .0000 & 67913.8500 & 3772.991667 & 11441.3279547 & 5.337 & .393 & 30.263 & .768 \\
\hline $\begin{array}{l}\text { NET WORTH (VALUE IN } \\
\text { CORE) }\end{array}$ & 36 & .0000 & 415303.4100 & 23025.194167 & 69571.8872782 & 5.432 & .393 & 31.042 & .768 \\
\hline
\end{tabular}

Table 5 point out correlation matrix table of MSME in India. The above table shows positive all the factors of MSME in India.

Table - 5. Correlation Matrix Table

CORRELATION MATRIX TABLE: 


\begin{tabular}{|c|c|c|c|c|c|c|c|c|c|}
\hline & $\begin{array}{l}\text { NUMBER OF } \\
\text { WORKING } \\
\text { CAPITAL }\end{array}$ & EMPLOYMENT & $\begin{array}{l}\text { ORIGINAL } \\
\text { VALUE OF P } \\
\& M\end{array}$ & $\begin{array}{l}\text { MARKET } \\
\text { VALUE OF } \\
\text { FIXED }\end{array}$ & $\begin{array}{l}\text { GROSS } \\
\text { OUTPUT }\end{array}$ & $\begin{array}{l}\text { TOTAL } \\
\text { INPUT }\end{array}$ & GVA & EXPORT & $\begin{array}{l}\text { NET } \\
\text { WORTH }\end{array}$ \\
\hline $\begin{array}{l}\text { NUMBER OF } \\
\text { WORKING CAPITAL }\end{array}$ & 1 & & & & & & & & \\
\hline EMPLOYMENT & 1.00 & 1 & & & & & & & \\
\hline $\begin{array}{l}\text { ORIGINAL VALUE } \\
\text { OF P \&M }\end{array}$ & 0.96 & 0.96 & 1 & & & & & & \\
\hline $\begin{array}{l}\text { MARKET VALUE } \\
\text { OF FIXED }\end{array}$ & 0.97 & 0.97 & 0.99 & 1 & & & & & \\
\hline GROSS OUTPUT & 0.98 & 0.99 & 0.94 & 0.95 & 1 & & & & \\
\hline TOTAL INPUT & 0.98 & 0.99 & 0.93 & 0.94 & 1.00 & 1 & & & \\
\hline GVA & 0.99 & 0.99 & 0.95 & 0.96 & 1.00 & 1.00 & 1 & & \\
\hline EXPORT & 0.99 & 0.99 & 0.93 & 0.94 & 0.99 & 0.99 & 0.99 & 1 & \\
\hline NET WORTH & 0.98 & 0.99 & 0.94 & 0.95 & 1.00 & 1.00 & 1.00 & 0.98 & 1 \\
\hline
\end{tabular}

SIMPLE REGRESSION ANNALYSIS (EMPLOYMENT AND OUTPUT)

Table - 6. Simple Regression Analysis of Employment and Output

Table 6

reveals that simple regression analysis (Employment and Output) of MSME in India. It shows R square is .982. The above calculation found $F$ value (1776.840). It is clear that difference between employment and Output was significant.

\begin{tabular}{|c|c|c|c|c|c|c|}
\hline \multicolumn{7}{|c|}{ Coefficients $^{a}$} \\
\hline \multirow{2}{*}{\multicolumn{2}{|c|}{ Model }} & \multicolumn{2}{|c|}{ Unstandardized Coefficients } & Standardized Coefficients & \multirow[t]{2}{*}{$\mathrm{t}$} & \multirow[t]{2}{*}{ Sig. } \\
\hline & & B & Std. Error & Beta & & \\
\hline \multirow[t]{2}{*}{1} & (Constant) & 587.290 & 2911.003 & & .202 & .841 \\
\hline & EMPLOYMENT(PERSON) & .075 & .002 & .991 & 42.153 & .000 \\
\hline
\end{tabular}

SIMPLE REGRESSION ANNALYSIS (OUTPUT AND FIXEED ASSETS)

Table - 7 Simple Regression Analysis of Output and Fixed Assets

Table 7

shows that simple regression analysis (Output and Fixed Assets). The R square shows .905. The above calculation found F (324.406). It is clear that difference between Output and Fixed Assets was significant.

\begin{tabular}{|c|c|c|c|c|c|c|}
\hline \multicolumn{7}{|c|}{ Coefficients $^{a}$} \\
\hline \multicolumn{2}{|c|}{ Model } & \multicolumn{2}{|c|}{ Unstandardized Coefficients } & \multirow{2}{*}{$\begin{array}{l}\text { Standardized Coefficients } \\
\text { Beta }\end{array}$} & \multirow[t]{2}{*}{$\mathrm{t}$} & \multirow[t]{2}{*}{ Sig. } \\
\hline & & B & Std. Error & & & \\
\hline \multirow[t]{2}{*}{1} & (Constant) & 1591.658 & 4271.246 & & .373 & .712 \\
\hline & GROSS OUTPUT & .630 & .035 & .951 & 18.011 & .000 \\
\hline
\end{tabular}

COBB-DOUGLAS PRODUCTION FUNCTION:

$Q=A L \beta 1 K \beta 2$.

ESTIMATED: A 1 1 \& $\beta 2$.

$L N(Q)=L N(A)$ beta1*LN (L) beta2*LN (K).

Table - 8 Cobb-Douglas Production Function 
Table 8

indicates COBB-DOUGLAS production function. The above table calculation found,

\begin{tabular}{|lllllllll|}
\hline & Coefficients & Standard Error & $\boldsymbol{t}$ Stat & $\boldsymbol{P}$-value & Lower 95\% & Upper 95\% & Lower 95.0\% & Upper 95.0\% \\
\hline Intercept & -0.53 & 1.09 & -0.49 & 0.63 & -2.75 & 1.69 & -2.75 & 1.69 \\
\hline B1 & 0.43 & 0.19 & 2.28 & 0.03 & 0.05 & 0.82 & 0.05 & 0.82 \\
\hline B2 & 0.54 & 0.16 & 3.43 & 0.00 & 0.22 & 0.87 & 0.22 & 0.87 \\
\hline & LN(A) & -0.53 & & & & & & \\
\hline "=EXP() & A & 0.59 & & & & & & \\
\hline
\end{tabular}

B1 Coefficient is 0.43 and standard error is 0.19

B2 Coefficient is 0.54 and standard error is 0.16

$\operatorname{LN}(\mathrm{A})=0.53$

$"=\operatorname{EXP}=A 0.59$

\section{ELASTICITY OF EMPLOYMENT AND EXPORT}

Employment elasticity captures the responsiveness of employment of changes in output. There are two common ways of measuring the output elasticity of employment (Mishra and Suresh, 2014). The first method calculates the point elasticity by regressing log-employment on log-output, where the coefficient on the latter is the estimate of elasticity. Since estimation of point elasticity relies on a regression, a researcher requires substantial data points to put it into practice. Often, enough data is not available to run regressions. In such cases, researchers turn to the second method, which calculates the arc elasticity as the ratio of the growth rate of employment and growth rate of output over some period of time. In this paper, we use data on employment from the Employment-Unemployment Survey (EUS) of the National Sample Survey Organisation (NSSO), which is available only every 5 years. This makes regression analysis infeasible. Hence, we compute and work with arc elasticities.

The arc employment elasticity for the aggregate economy is defined as.

\section{$\log E=a+b \log Y$}

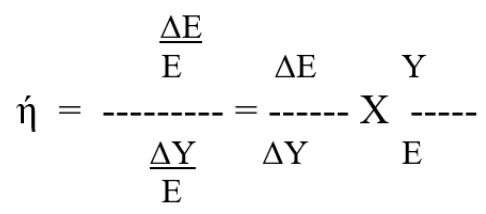

Where $E$ denotes employment, $\mathrm{Y}$ denotes real output (value added) and $\Delta \mathrm{x}$ stands for change in the variable $\mathrm{x}$.

\section{ELASTICITY OF EMPLOYMENT OUTPUT}

Table - 9 Elasticity of Employment

\begin{tabular}{|c|c|c|c|c|c|}
\hline \multicolumn{6}{|l|}{ Coefficients } \\
\hline & \multicolumn{2}{|c|}{ Unstandardized Coefficients } & Standardized Coefficients & \multirow[t]{2}{*}{$\mathrm{t}$} & \multirow[t]{2}{*}{ Sig. } \\
\hline & $\mathrm{B}$ & Std. Error & Beta & & \\
\hline In(EMPLOYMENT(PERSON)) & 11225.697 & 1636.220 & .772 & 6.861 & .000 \\
\hline (Constant) & -106764.877 & 18814.515 & & -5.675 & .000 \\
\hline
\end{tabular}

\section{ELASTICITY OF EXPORT}

Table - 10 Elasticity of Export. 
Table 9

indicates Elasticity of Employment. From the above table calculated value of $F$ (47.070). Unstandardized coefficients B value is 11225.697 and standardized coefficient Beta is .772 which shows elasticity of employment is significant.

\begin{tabular}{|c|c|c|c|c|c|}
\hline \multicolumn{6}{|l|}{ Coefficients } \\
\hline & \multicolumn{2}{|c|}{ Unstandardized Coefficients } & Standardized Coefficients & \multirow[t]{2}{*}{$\mathrm{t}$} & \multirow[t]{2}{*}{ Sig. } \\
\hline & B & Std. Error & Beta & & \\
\hline EXPORT(VALUE IN CORE) & 92.612 & 12.625 & .792 & 7.336 & .000 \\
\hline (Constant) & 88810.256 & 47526.637 & & 1.869 & .071 \\
\hline
\end{tabular}

Table 10 shows Elasticity of Export of MSME in India. The above table calculated value of F (53.811), unstandardized coefficients B is 92.612 and standardized coefficients Beta value is .792. It indicates Elasticity of Export is significant.

\section{DESCRIPTIVE STATISTICS}

\begin{tabular}{|c|c|c|c|c|c|c|c|c|c|c|c|}
\hline \multicolumn{12}{|l|}{ Descriptive Statistics } \\
\hline & $\mathrm{N}$ & Range & Minimum & Maximum & Mean & $\begin{array}{l}\text { Std. } \\
\text { Deviation }\end{array}$ & Variance & Skewness & & Kurtosis & \\
\hline & Statistic & Statistic & Statistic & Statistic & Statistic & Statistic & Statistic & Statistic & $\begin{array}{l}\text { Std. } \\
\text { Error }\end{array}$ & Statistic & $\begin{array}{l}\text { Std. } \\
\text { Error }\end{array}$ \\
\hline $\begin{array}{l}\text { INPUT OUT PUT } \\
\text { RATIO OF GROSS } \\
\text { OUT PUT \& TOTAL } \\
\text { INPUT }\end{array}$ & 35 & 2 & 1 & 3 & 1.86 & .494 & .244 & -.349 & .398 & .971 & .778 \\
\hline $\begin{array}{l}\text { PERCENTAGE OF } \\
\text { EXPORT }\end{array}$ & 35 & $18.00 \%$ & $1.00 \%$ & $19.00 \%$ & $5.7714 \%$ & $5.04151 \%$ & 25.417 & .905 & .398 & -.127 & .778 \\
\hline $\begin{array}{l}\text { RATIO OF NET } \\
\text { GROWTH RATE TO } \\
\text { TATAL OUTPUT }\end{array}$ & 35 & 4 & 0 & 4 & 1.23 & .808 & .652 & 2.037 & .398 & 4.434 & .778 \\
\hline Valid N (list wise) & 35 & & & & & & & & & & \\
\hline
\end{tabular}

In Descriptive statistics shows average input output ratio is 1.86. Percentage of Export average is 5.7714 percent and ratio of net growth rate of total output 1.23. The standard deviation .494 in input output ratio, 5.04151 percent in percentage export and .808 ratio of net growth. The variance shows .244 in input output ratio, 25.417 in percentage of export and 2.037 in ratio of net growth rate of total output. Skewness standard error indicates .398 in all factors and Kurtosis standard error point out .778 each in all three factors. Now the descriptive statistics indicates the positive in MSME sector in India.

\section{Conclusion}

The empirical results of the present note based on the positive magnitude of elasticity employment with elasticity of export. This reflects the fact that the employment absorption capacity in MSME sector has been high followed by the other sectors. The current period evincing the fact that the reforms have deteriorated the employment opportunities in this sector. The magnitude of output elasticity of employment is close to unity in manufacturing sector as the employment elasticity has increased. The result of this exercise for the organized sector as a whole illustrate that the output elasticity of employment during the study period is very low as compared to the output elasticity of employment. Output elasticity of employment showing that the economic growth during current period is not labour intensive. The objective of providing employment opportunities not only for the additions to the employee force, but also reduce the backlog of unemployment accumulated from the past is not attained in the Indian Economy.

\section{Declarations}

\section{Availability of data and materials}

Data for the research is kept by the different Sources like Source: MSME Annual Report 2017-18, Gol,Source: Union Ministry of Finance, Economic Division (2016), Economic Survey 2015-16, New Delhi., Source: Economic Survey 2001-02, Government of India, Ministry of Finance, Economic Division.

\section{Funding}

I am very much thankful to my Alma matter Berhampur University, Odisha and UGC providing me such a platform to enhance and enrich my research career. 


\section{Authors' contributions}

There is two author in this article. Two authors have huge taking lot of pain taking contribution to make this article at this level.

\section{Acknowledgements}

This is best of my knowledge that this article have not published any other National, International and any UGC- Care journal.

\section{Authors' information}

There are two author in this article:

1. Setak Palak, Research Scholar, Department of Economics, Berhampur University, Bhanjabihar, Email: setakompalak@gmail.com, Mob: 9090914843.

2. Dr.sandhyarani Das, Associate Professor, Department of Economics, Berhampur

University,Bhanjabihar,Email:srd1407@gmail.com.Mob:9437203939.

\section{References}

1. Admassie, A., \& Matambalya, F. (2002), Technical Efficiency of Small and Medium Enterprises: Evidence from a Survey of Enterprises in Tanzania, MUSE Project.

2. Department of Economics, University of Massachusetts, Amherst, USA. Email: dbasu@econs.umass.edu, Department of Humanities and Social Science, Indian Institute of Technology, Guwahati, India. Email: debarshidas@iitg.ernet.in.

3. Economic Survey 2001-02, Government of India, Ministry of Finance, Economic Division.

4. For the sake of brevity, henceforth we will refert o "output elasticity of employment" as "employment elasticity".

5. ILO 2013; “Global Employment Trends 2013”, International Labour Office, Geneva. http://www.ilo.org/wcmsp5/groups/public/--dgreports/--dcomm/-publ/documents/publication/wcms_202326.pdf.

6. Kumar, M. And, \& Basu, P. (2008). point out Perspectives of Productivity Growth in Indian Food Industry: A Data Envelopment Analysis. International Journal of Productivity and Performance Management, 57(7), 503-522.

7. Majumder, R. (2004), Productivity Growth in Small Enterprises - Role of Inputs, Technological Progress and Learning by doing, MPRA Paper No. 4848.

8. Mishra, S., \& Suresh, A. K. (2014), “Estimating Employment Elasticity of Growth for the Indian Economy,” WPS (DEPR): 06/2014, RBI Working Paper Series, Department of Economic and Policy Research, Reserve Bank of India.

9. There is the important consideration of quality of jobs that are being created. But the creation of jobs itself remains a major challenge.

10. Zahid, Z., \& Mokhtar, M. (2007), Estimating Technical Efficiency of Malaysian Manufacturing Small and Medium Enterprises: A Stochastic Frontier Modelling, The 4th SMEs in a Global Economy Conferences, University of Wollongong, 9-10 July.

\section{Figures}

\section{EMPLOYMENT AND TOTAL OUT PUT}

m Series1 $\mid$ Series2

Figure 1

Page 10/11 
Graph 2

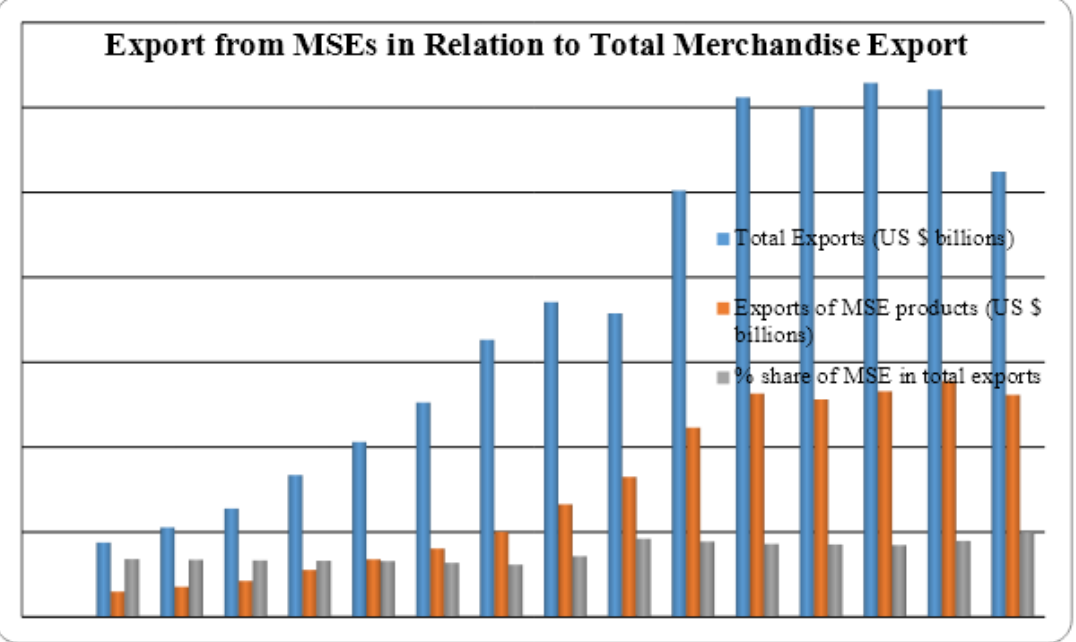

Figure 2

Graph 1 